\title{
PENGARUH POLA ASUH ORANG TUA TERHADAP KECERDASAN EMOSIONAL AUD TK MUSLIMAT NU 1 TUBAN
}

\author{
Kholifah \\ PG PAUD, FKIP, Universitas PGRI Ronggolawe, Tuban, Indonesia \\ e-mail: kholifahdra10@gmail.com
}

\begin{abstract}
Abstrak
Belakangan ini, masyarakat sekitar kita semakin banyak yang perilakunya melanggar norma, merugikan orang lain, dan tidak dapat menghargai sesama. Perilaku-perilaku tersebut merupakan indikasi tidak dimilikinya kecerdasan emosi. Kecerdasan emosi merupakan kemampuan untuk mengelola dan mengendalikan emosi. Kecerdasan emosi diperlukan untuk mencapai kesuksesan dalam menjalani kehidupan yang penuh dengan tantangan. Kemampuan ini seharusnya ditanamkan pada anak sejak usia dini agar tertanam kuat dan menjiwai perilaku anak. Keluarga merupakan kelompok sosial terkecil, pertama dan utama tempat anak belajar apapun, melalui pembiasaan dan permodelan. Pola pengasuhan anak-anak menjadi tanggung jawab keluarga, karena hal tersebut dapat mempengaruhi dalam membentuk perilaku anak. Permasalahannya, apakah pola asuh orang tua dapat berpengaruh terhadap kecerdasan emosional anak usia dini dan pola asuh orang tua mana yang lebih besar dapat mempengaruhi kecerdasan emosional anak usia dini pada TK Muslimat NU I Tuban. Tujuannya, mendiskripsikan pengaruh pola asuh orang tua terhadap kecerdasan emosi anak usia dini dan mendiskripsikan pola asuh orang tua yang lebih besar dapat mempengaruhi kecerdasan emosi anak usia dini pada TK Muslimat NU I Tuban. Jenis penelitian ini ialah kuantitatif, dengan jumlah populasi sebanyak 67 siswa dan setelah sampel ditentukan secara purposive sampling, didapatkan sampel sejumlah 40 siswa. Metode pengumpulan data, meliputi angket pengukuran gaya orang tua/pola asuh orang tua, angket pengukuran kecerdasan emosional anak usia dini, observasi, wawancara, dan dokumentasi. Analisa data statistik menggunakan program SPSS regresi linear berganda. Hasil penelitian ini ialah $F$ hitung $>F$ tabel $(33,144>2,641)$ dan signifikansi $<0,05 \quad(0,000<0,05)$, artinya kecerdasan emosional anak usia dini dapat dipengaruhi secara bersama oleh empat macam gaya orang tua/pola asuh orang tua $(\mathrm{X} 1, \mathrm{X} 2$, $\mathrm{X} 3, \mathrm{X} 4) . \mathrm{Y}^{\prime}=51,959+0,016 \mathrm{X} 1+0,199 \mathrm{X} 2+0,184 \mathrm{X} 3+0,293 \mathrm{X} 4$, artinya yang paling besar pengaruhnya di antara empat gaya orang tua/pola asuh orang tua ialah gaya orang tua/pola asuh orang tua pelatih emosi (X4).
\end{abstract}

Kata Kunci: pola asuh orang tua, kecerdasan emosional

\section{EFFECT PATTERNS PARENTING ON EMOTIONAL INTELLIGENCE AUD TK MUSLIMAT NU 1 TUBAN \\ Abstract}

In recent times, the people around us are increasingly violating the norms, harming others, and not being able to respect others. These behaviors are indicative of not having emotional intelligence. Emotional intelligence is the ability to manage and control emotions. Emotional intelligence is needed to achieve success in living a life full of challenges. This ability should be instilled in children from an early age to be firmly entrenched and animate the child's behavior. The family is the smallest social group, first and foremost where the child 
Jurnal Pendidikan Anak, Volume 7, Edisi 1, Juni 2018

learns anything, through habituation and modeling. The pattern of parenting is the responsibility of the family, because it can affect in shaping the child's behavior. The problem is whether parental parenting can have an effect on the emotional intelligence of early childhood and which parenting pattern can influence the emotional intelligence of early childhood in NU I Tuban kindergarten. The aim, to describe the influence of parenting parenting to emotional intelligence of early childhood and to describe the pattern of parents greater parenting can affect the emotional intelligence of early childhood in NU I Tuban kindergarten I Tuban. The type of this research is quantitative, with the total population of 67 students and after the sample is determined by purposive sampling, obtained a sample of 40 students. Methods of data collection, including questionnaire parenting style / parenting style, questionnaire measurement of emotional intelligence of early childhood, observation, interviews, and documentation. Analysis of statistical data using multiple linear regression SPSS program. The result of this research is $\mathrm{F}$ count $>\mathrm{F}$ table $(33,144>2,641)$ and significance $<0,05(0,000<0,05)$, meaning that early child emotional intelligence can be influenced together by four kinds of parent / parenting style $(\mathrm{X} 1, \mathrm{X} 2, \mathrm{X} 3, \mathrm{X} 4) . \mathrm{Y}^{\prime}=51,959+0.016 \mathrm{X} 1+$ $0,199 \mathrm{X} 2+0,184 \mathrm{X} 3+0,293 \mathrm{X} 4$, meaning that the most influence between four parent styles / parenting pattern is parent / parenting style of emotional coach parents (X4).

Keywords: patterns Parenting, Emotional Intelligence

\section{PENDAHULUAN}

Lingkungan awal atau pertama dan utama anak ada didalam keluarga, oleh karena itu keluarga harus menyadari penuh akan hal tersebut. Orang tua memiliki peranan yang sangat vital dan menentukan bagi anak. Melalui arahan dan bimbingan dari orang tua akan dapat menentukan perkembangan dan masa depan anak. Banyak faktor yang berpengaruh terhadap perkembangan perilaku anak, dan salah satu faktor tersebut yaitu pola asuh orang tua atau gaya orang tua menjadi orang tua. Pola asuh orang tua merupakan sikap dan perilaku orang tua dalam mengasuh anakanaknya. Meskipun pola ini akan berubah dengan semakin besarnya bayi atau anak dan meluasnya lingkungan, tetapi pola intinya cenderung tetap. Inilah sebabnya mengapa hubungan ayah ibu dan anggota keluarga lainnya dalam pengasuhan, merupakan unsur penting bagi perkembangan anak, hal tersebut dapat berupa gaya menjadi orang tua atau bentuk- bentuk pola asuh orang tua terhadap anakanaknya.

Menjalani kehidupan yang "sukses" pada zaman sekarang, tidak hanya mengandalkan kecerdasan intelektual semata. Hal ini didasari hasil penelitian yang memberikan deskripsi bahwa tingkat kecerdasan intelektual yang tinggi tidak lagi menjadi satu-satunya andalan manusia untuk bisa bertahan dan mengembangkan diri. Kecerdasan emosi merupakan sesuatu yang harus dimiliki oleh setiap manusia, selain kecrdasan intelektual dan kecerdasan spiritual. Kecerdasan emosi merupakan kemampuan seseorang dalam mengelola emosinya atau mengendalikan emosinya. Dengan dimilikinya kecerdasan emosi orang akan mampu merespon dan mereaksi suatu rangsangan sesuai dengan porsinya atau tidak dengan berlebihan. Kemampuan "berpikir" dan "merasa" akan jalan seiring dan seimbang, sehingga akan muncul perilaku manusia yang cenderung tidak merugikan siapapun. Dengan dimilikinya kecerdasan emosional oleh setiap orang, 
merupakan modal untuk mencapai kesuksesan dalam kehidupan. Tetapi apa yang telah terjadi pada kehidupan ditengahtengah masyarakat sekitar kita, yaitu semakin banyaknya tindakan kejahatan, tindakan merugikan orang lain, dan tindakan tidak menyenangkan, Perampokan, perkosaan, korupsi, menfitnah, tidak bertanggung jawab, dan lain sebagainya, merupakan realita lemahnya masyarakat dalam mengendalikan diri atau ketidakmampuannya didalam mengelola emosinya.

Anak usia dini sebagai generasi penerus bangsa, maka anak-anak tersebut harus berkualitas, sehingga pada saatnya nanti anak-anak dapat sukses menjalani kehidupan. Harapan luhur tersebut harus diujudkan oleh orang tua dan guru, dengan memberikan salah satu bekal hidup yang penting, yaitu dengan dimilikinya kecerdasan emosi. Agar kemampuan tersebut dapat tertanam kuat dan dapat menjiwai perilaku anak-anak, maka harus ditanamkan sejak usia dini oleh orang tua. Membimbing anak agar memiliki kecerdasan emosional bukanlah hal yang mudah, oleh karena perlu diupayakan dengan sungguh-sungguh. Upaya tersebut dapat melalui penerapan gaya orang tua/pola asuh orang tua yang tepat. Hasil penelitian Hidayah, R., Eka Y., Yulian W. U. (2013), bahwa ada korelasi positif sebesar 0,909 dan memiliki nilai signifikansi $0,000(\mathrm{p}<0,05)$ artinya ada hubungan pola asuh orang tua dengan kecerdasan emosi anak usia dini. Hasil penelitian lain, Pujiharti, I. dan Mathilda, R.H., hasil uji Chi Square 6,359 dengan nilai X2 tabel 3,841 artinya X2 tabel lebih kecil dari X2 hasil, artinya ada hubungan pola asuh orang tua dengan kecerdasan emosi anak usia dini. Dengan latar belakang tersebut maka nampak sekali betapa pentingnya tentang dimilikinya kecerdasan emosional oleh setiap manusia, oleh karena itu dilakukan penelitian tentang "Pengaruh Pola Asuh Orang Tua Terhadap Kecerdasan Emosi Anak Usia Dini di TK Muslimat NU I Tuban".

\section{Pola Asuh Orang Tua \\ Pengertian}

Menurut pendapat Susanto (2015:26), pola asuh ialah pola interaksi antara anak dan orang tua selama anak dalam pengasuhan. Pada proses pengasuhan tersebut, selain bagaimana orang tua memperlakukan anak, juga tentang cara orang tua dalam mendidik, membimbing, menanamkan disiplin, dan melindungi anak. Dengan harapan nantinya akan menjadi individu yang memiliki kedewasaan sesuai dengan norma yang berlaku di masyarakat pada umumnya. Dalam menjalankan tugas pengasuhannya, dapat berupa sikap-sikap orang tua terhadap anak-anaknya. Yaitu meliputi, bagaimana aturan-aturan diterapkan, saat memberikan hadiah maupun hukuman, cara orang tua menunjukkan otoritas dan juga cara orang tua memberikan perhatian serta tanggapan kepada anaknya. Jadi pola asuh merupakan cara orang tua menjalankan pengasuhan kepada anak-anaknya sebagai kewajiban yang tidak tergantikan oleh siapapun, dan bentuk tanggung jawab sebagai sebuah lembaga terkecil dari sebuah masyarakat. Dalam pendapat lain yang tentunya tidak mengurangi esensi dan makna pola asuh orang tua disebut dengan gaya orang tua menjadi orang tua.

\section{Macam Pola Asuh}

Sehubungan dengan macam pola asuh, Susanto (2002:26) membagi pola asuh dalam tiga kecenderungan, yaitu :

1) Pola asuh Otoriter, cirinya tegas, suka menghukum, kurang kasih sayang, kurang simpati. Orang tua suka memaksa anak-anaknya untuk patuh terhadap nilainilai mereka, serta mencoba membentuk tingkah laku anak sesuai dengan pola 
tingkah laku orang tua, serta cenderung mengekang keinginan anak. Orang tua tidak mendorong anak untuk mandiri, hak anak sangat dibatasi dan sudah diserahi tanggung jawab yang terlalu membebani anak. Menurut Stewrt \& Koch (1983) dalam Susanto (2002:26) orang tua yang otoriter mempunyai ciri yang selalu kaku, suka menghukum, tidak menunjukkan perasaan kasih sayang dan tidak simpatik. Mereka selalu melihat anak-anak dari segi kepatuhan terhadap otoritas orang tua, tragisnya sikap orang tua yang otoriter mempunyai kecenderungan memberi hukuman terutama hukuman fisik.

Efek orang tua yang otoriter pada umumnya membentuk perilaku anak yang bingung, mudah tersingung, dengan ciri-ciri antara lain takut, gelisah, agresif dan suka menyendiri, murung dan sedih. Anak-anak bersikap tidak simpatik tidak puas, mudah curiga, kurang inisiatif mudah gugup raguragu, suka membangkang, suka menentang kewibawaan orang tua, kemungkinan menjadi penakut atau terlalu menurut (Susanto, 2002: 27).

2) Pola asuh Demokrasi, menurut Susanto (2002:28) orang tua yang berpola asuh demokrats biasanya bersifat hangat dan dekat dengan anak, menyebutkan standar yang jelas pada anak-anaknya, menerapkan dan mengkomunikasikan aturan dengan ketat dan jelas, tidak menyukai anak nakal, tidak segan menerapkan hukuman fisik dalam batasbatas tertentu secara konsisten apabila anak melakukan kesalahan berulang-ulang, dan memberi hadiah apabila mendapatkan prestasi dan memberi dukungan apabila anak melakukan kegiatan yang konstruktif. Efek orang tua yang demokrasi umumnya membentuk perilaku anak yang energik dan bersahabat dengan ciri-ciri, mandiri, memiliki energi yang tinggi, mampu mengendalikan diri, ceria, ramah, mudah bekerja sama dengan orang lain (teman sebaya atau yang lebih dewasa), mempunyai kemampuan untuk menghadapi dan menanggulangi kemungkinan adanya tekanan-tekanan (stress).

3) Pola asuh Permisif, merupakan pola asuh yang cnderung memberi kebebasan pada anak dengan kontrol yang sangat longgar, anak dibiarkan semaunya sendiri, seolah memanjakan anak secara berlebihan, selalu menuruti permintaan anak, dan orang tua tidak banyak mengatur. Orang tua tidak jelas mengkomunikasikan aturan pada anak, tidak konsisten menanamkan disiplin, tetapi cukup hangat terhadap anak-anaknya (Susanto, 2002:29). Menurut Hurlock (1982) pola asuh permisif bercirikan adanya kotrol yang kurang, orang tua bersikap longgar dan bebas, bimbingan pada anak tidak banyak dilakukan.

Efek pola asuh permisif akan menjadikan anak yang berperilaku liar tanpa kontrol, masa bodoh, anak bebas bertindak semaunya, komunikasi jarang terjadi, anak akan tidak patuh dan menentang aturan, kurang percaya diri, kontrol diri kurang, cenderung agresif, impulsif dan tidak mempunyai tujuan. Demikian juga menjadi penyebab anak kurang matang, penuh ketergantungan dan tidak bahagia, berkepribadian kacau, selalu curiga pada orang lain, dan sulit untuk diajak kerja sama, tidak memiliki rasa simpati pada orang tua, emosi tidak stabil, selalu diliputi perasaan tidak puas.

Hurlock (1974:355) pola asuh orang tua pada anaknya terdiri empat macam yang sifatnya bipolar artinya berpasangan dan saling berlawanan) yaitu, 1) toleran dan tidak toleran; 2) permisif dan ketat; 3) membiarkan dan turut terlibat; 4) hubungan dingin dan hubungan hangat.

Menurut Syaodih (1999: 26-31) pola asuh yang positif pada anak usia dini berprinsip pada :

1) Pola asuh dengan prinsip keakraban yaitu, didasari akan kasih sayang, dan 
kehangatan, serta kedekatan senantiasa ada antara yang satu dengan yang lain. Ibu akan mendekati anak-anaknya dengan menampilkan sikap keibuan saat membimbingnya. Perasaan ibu tidak terlibat dan tidak terpengaruh walaupun menghayatinya. Dalam membimbing memerlukan tidak hanya naluri keibuan semata tetapi juga memerlukan kesadaran yang sangat tinggi. Mencurahkan kasih sayang yang berlebihan dapat menimbulkan kesan memanjakan. Demikian juga hubungan menjadi dingin, gersang, sunyi, karena kurang sekali kasih sayang. Yang harus dijadikan patokan oleh orang tua ialah kasih sayang atas dasar tanggung jawab dan menuntut tanggung jawab pula.

2) Pola asuh dengan prinsip kepedulian yaitu, didasari prinsip kepedulian (perhatian, minat, kesungguhan). Perhatian yang diberikan kepada anak tentang apa yang dibutuhkan, apa yang dirasakan, mendengar dan menjawab pertanyaan dengan wajar artinya sesuai dengan usia anak. Perkembangan kepribadian yang wajar akan didapat anak, apabila orang tua menunjukkan kepeduliannya dengan selalu memberikan bimbingan kepada anak-anaknya.

3) Pola asuh dengan prinsip kebebasan yaitu, didasari prinsip kebebasan, anak diberi kebebasan tanpa ragu-ragu untuk memilih, mengemukakan pendapatnya. Dalam membimbing anak-anaknya, orang tua senantiasa merangsang agar anakanaknya mau berdialog dengan tanpa keragu-raguan, terarah, dan menerima kebebasan dengan penuh rasa tanggung jawab. Kebebasan yang diberikan bukan tanpa batas tetapi tetap ada kontrol. Artinya bukan kebebasan tanpa dasar dan pegangan, tetapi kebebasan atas dasar ketentuanketentuan. Sebagai manusia memiliki tugas dan tanggung jawab terhadap penciptaNya, sebagai konsekwensi keterikatan terhadap hukum-hukum kehidupan.
4) Pola asuh dengan prinsip kemandirian yaitu, semula orang tua tidak segan-segannya mengarahkan, mendorong, membiasakan, agar anak melakukannya sendiri. Secara berangsur-angsur anak menjadi terlatih/terbiasa, lama kelamaan anak akan melakukannya sendiri. Pelaksanaan pola ini tidak mudah berlangsung dengan baik sedangkan sebenarnya merupakan pola asuh yang ideal. Karena tidak tega, sering orang tua masih membantu apa yang dikerjakan anak, sedangkan sebenarnya anak masih mampu mengerjakannya.

5) Pola asuh dengan prinsip kedisiplinan yaitu, merupakan pola asuh yang lekat dengan diikutinya peraturanpeaturan. Menurut Abdullah (dalam Susanto, 2002) disiplin merupakan perangkat kegiatan atau latihan yang terencana yang diperlukan untuk mencapai tujuan tertentu (disiplin positif). Disiplin merupakan hukuman terhadap perilaku yang tidak diinginkan (disiplin negatif). Tujuannya ialah untuk menghindarkan perilaku yang tidak diinginkan, membantu individu supaya memahami apa yang diperlukan untuk mencapai tujuan dan untuk mendorong agar orang memelihara dan mematuhi latihan atau aturan yang sudah dikembangkan. Prinsip bimbingan harus dijalankan dalam menanamkan kedisiplinan sebagai sesuatu yang mendasar pada anak. Merupakan langkah esensial dalam bimbingan, apabila penanaman disiplin pada anak oleh orang tua senantiasa berlangsung melalui hubungan yang baik. Selanjutnya anak dapat introspeksi tentang mengapa ada pelanggaran, apa yang harus diperbuat, dan apa akibat buat dirinya ataupun buat orang lain.

6) Pola asuh dengan prinsip realistik yaitu, pola asuh yang berorientasi pada kenyataan atau kenyataan hidup. Anak diajarkan untuk dapat hidup dengan menerima sesuatu apa adanya, sesuatu yang 
sesuai dengan kemampuannya, fasilitas dengan kondisi yang ada. Orang tua dituntut untuk menyatakan sesuatu dengan jujur, tidak mencari-cari alasan untuk membuat anak menjadi senang.

7) Pola asuh dengan prinsip emosi stabil yaitu, diharapkan dalam pengasuhan anak, orang tua senantiasa tidak menunjukkan emosi yang negatif (penuh ketegangan, sikap marah, sedih, cemas, cepat tersinggung) dan sikap-sikap yang lainnya. Sebagai orang tua harus terus belajar untuk dapat mengendalikan emosi, agar siap menghadapi perilaku dan kemauan anak-anaknya yang beranega ragam..

Adapun menurut Lazarus (1876: 242) jenis pola asuh orang tua terhadap anaknya, digambarkan sebagai sikap mengabaikan, melindungi yang berlebihan, memiliki yang sekehendak hati, menerima, hangat, bermusuhan, menoak, dan lainnya (parental attitudes toward the child can be described as neclectful, overprotective, possessive, rejecting and so on).

Gottman dan DeClaire (1999:43) membagi gaya menjadi orang tua (pola asuh) dalam empat gaya, yaitu:

1) Gaya orang tua mengabaikan, orang tua terbiasa langsung menyelesaikan masalah anak atau membereskan semua kepedihan anak, tidak terlebih dahulu menanyakan apa yang dirasakan anak, berupaya tidak terjadi rasa yang tidak mengenakkan pada anak, anak tidak bisa dengan sendirinya merasakan apa yang dirasakan tetapi orang tua yang mengajarkan rasa itu, memperkecil/meremehkan kesedihan anak dan permasalahan anak, menutupinya dan membuangnya untuk dilupakan atau dengan mengalihkan, orang tua merasa takut anak akan emosional dan kehilangan kendali. Akibat gaya orang tua mengabaikan adalah: mereka belajar bahwa perasaannya itu keliru, tidak tepat atau tidak sah, boleh jadi mereka belajar bahwa "dari sananya" ada sesuatu yang salah dengan mereka karena cara mereka merasa, boleh jadi mereka menghadapi kesulitan untuk mengatur emosi-emosi mereka.

2) Gaya orang tua tidak menyetujui, orang tua mencolok kritis dan tidak berempati, penuh curiga terhadap pengalaman emosi anak, tidak memahami anak tetapi lebih cenderung memperhatikan tingkah laku disekitar emosi anak, memanfaatkan situasi remeh sebelum menentukan tindakan, takut emosi susah dikendalikan, anak tidak diberi kesempatan mengalami emosi-emosi mereka dan mengatasi secara efektif jadinya anak tidak siap menghadapi tantangan. Akibat gaya orang tua yang tidak menyetujui adalah: mereka belajar bahwa perasaannya itu keliru, tidak tepat atau tidak sah, boleh jadi mereka belajar bahwa "dari sananya" ada sesuatu yang salah dengan mereka karena cara mereka merasa, boleh jadi mereka menghadapi kesulitan untuk mengatur emosi-emosi mereka (sama dngan tipe mengabaikan).

3) Gaya orang tua Laissez Faire (bahasa latin, artinya biarkan saja), orang tua penuh empati (apapun boleh), biarkan anak mengungkapkan emosi semaunya "pekerjaan kita selesai", cenderung tidak trampil tidak bersedia membimbing bagaimana mengatasi emosi negatif, sedikit kesadaran bagaimana menolong anak untuk belajar dari pengalaman emosional, tidak yakin tenang apa yang harus diajarkan, suka menerima reaksi anak tanpa memberi, anak tidak bisa menenangkan diri/mengatasi emosi, tidak memberi pedoman mengelola emosi, membebaskan anak melepaskan emosi dengan ungkapan emosi yang tidak tepat/bebas. Akibat dari orang tua yang laissez faire adalah : anak tidak belajar mengatur emosinya, anak mengalami kesulitan dalam berkonsentrasi, dalam 
menjalin persahabatan, bergaul dengan anak lain.

4) Gaya orang tua pelatih emosi, di dalam menjalankan peran sebagai pelatih emosi memerlukan interaksi dalam lima langkah, yaitu : 1) menyadari emosi anaknya; 2) mengakui emosi itu sebagai peluang untuk kedekatan dan mengajar; 3) mendengarkan dengan penuh empati dan meneguhkan perasaan anak; 4) menolong anaknya menemukan kata-kata untuk memberi nama emosi yang sedang dialaminya; 5) menemukan batas-batas sambil membantu anak memecahkan masalah yang dihadapi.

Orang tua dengan gaya ini mampu menerima perasaan anak dan tidak mencemooh serta tidak meremehkan, memandu anak dalam menempuh dunia emosi, melangkah lebih jauh dari pada menerima dan mematok batas-batas tingkah laku yang tidak tepat, mengajar anak tentang bagaimana mengatur perasaan untuk menemukan ungkapan-ungkapan yang tepat, dan memecahkan masalahmasalah, mengambil sisi positif dari sesuatu yang kita anggap negatif, memberikan penghargaan atas pernyataan emosi-emosi anak dan mereaksi dengan cara-cara yang baik, mendorong akan kejujuran emosi anak, mampu menghentikan tingkah laku yang merugikan dan mengarahkan kembali ke kegiatan atau ungkapan yang tidak merugikan, tidak melindungi anak terhadap emosi yang tidak menyenangkan agar anak mendapat pengalaman dan bagaimana mengaturnya, orang tua tidak langsung membereskan kesulitan/persoalan anak, orang tua tidak segan-segan menunjukkan emosi mereka didepan anak-anak, bersedia meminta maaf pada anak-anak bila salah.

Maka dari itu orang tua yang pelatih emosi memiliki keuntungan pada keluarganya, yaitu: 1) orang tua konsisten tanggap terhadap anak-anak mereka bila perasaan masih ada pada intensitas yang rendah tingkatannya. Artinya emosi tidak perlu meningkat sebelum anak memperoleh perhatian yang dicarinya. Lama kelamaan anak akan mendapat kesan bahwa orang tuanya memperhatikan, memahamai, berempati dalam kehidupan mereka. Mereka tidak usah melampiaskan marahnya untuk mendapatkan perhatian dari orang tua. 2) Jika anak mendapat pelatihan sejak dini anak akan dapat menghibur diri dan tetap tenang walaupn mendapat tekanan batin dan ini menyebabkan untuk tidak terjadinya tindakan yang keliru, 3) Orang tua tidak menyangkal emosi-emosi mereka sehingga mengurangi pertentangan, karena ada batas-batas dan pesan-pesan yang jelas serta konsisten tentang perilaku sehari-hari, sehinnga menjadi orang tua pelatih emosi membuat ikatan-ikatan emosi antara anak dan orang tua menjadi kuat, oleh karena itu anak akan tanggap terhadap permintaanpermintaan orang tua. Anak-anak melihat orang tua sebagai sekutu mereka, mereka ingin menyenangkan dan mereka tidak ingin mengecewakan. Akibat dari gaya orang tua pelatih emosi pada anak adalah: anak belajar mempercayai perasaanperasaannya, mengatur emosinya sendiri, menyelesaikan masalah-masalahnya, memiliki harga diri yang tinggi, belajar dengan baik, dan bergaul dengan orang lain dengan baik.

\section{Kecerdasan Emosi}

\section{a. Pengertian}

Pada realita kehidupan sehari-hari masih sering ditemui kurang tepatnya mengartikan kata emosi. Sering sekali emosi diartikan dengan marah ataupun dinisbatkan/ditetapkan dengan keadaan marah (Wiyani, 2014:21) Sehingga orang yang pemarah disebut orang yang emosional. Bagaimna jika sifat (pemarah) dibandingkan dengan kecerdasan emosi, yang diartikan kepandaian sesorang dalam mengelola perasaanya sehingga menimbulkan perilaku-perilaku yang 
positif, maka akan semakin tidak sebanding. Emosi dalam makna yang paling harfiah didefinisikan sebagai setiap kegiatan atau pergolakan pikiran, perasaan, nafsu dari setiap keadaan mental yang hebat atau meluap-luap. Emosi secara bahasa berarti luapan perasaan yang berkembang dan surut dalam waktu yang singkat (Wiyani, 2014;21). Emosi adalah perasaan yang sedang bergejolak artinya suatu keadaan perasaan yang meninggi dan tidak biasa-biasa saja terhadap sesuatu.

Rasa atau perasaan merupakan keadaan seseorang yang merespon sesuatu yang dihayati dengan rasa suka atau tidak suka. Emosi juga dapat berupa keadaan dan reaksi psikologis serta fisiologis seseorang, seperti kegembiraan, kesedihan, keharuan, kecintaan, dan kemarahan (Alwi, dkk.: 2002). Secara bahasa, berarti perasaan yang melingkupi seseorang pada suatu waktu tertentu. Ada perasaan senang, suka, cinta, dan lain sebagainya adalah perasaan positif. Sedangkan rasa benci, marah sedih, kecewa, takut, cemas, dan lain sebagainya adalah perasaan negatif. Menurut Aliah B. Purwakania membagi emosi menjadi dua macam, yaitu: 1) Emosi Primer, adalah emosi dasar yang secara biologis sudah ada pada manusia sejak awal, faktor yang dibawa mulai kelahirannya, seperti senang, sedih, takut, dan marah;2) Emosi Sekunder, keberadaan emosi ini lebih komplek dari emosi primer, yaitu mengandung kesadaran diri atau evaluasi diri yang perkembangannya tergantung pada perkembangan kognitif atau intelektual seseorang. Jadi kesimpulannya emosi adalah perasaan individu, yang positif maupun negatif sebagai respon terhadap suatu keadaan yang melingkupinya, karena adanya hubungan antara manusia dengan lingkungannya atau suatu kelompok.

Menurut Wiyani (2014:98) kecerdasan, secara bahasa berasal dari kata cerdas yang berarti sempurna perkembangan akal budinya (untuk berfikir, mengerti, memahami, dan sebagainya). Kecerdasan emosional dapat diartikan kemampuan seseorang individu dalam mengelola perasaannya saat dia berhubungan dengan dirinya sendiri, sesamanya, dan makhluk lain di alam sekitar (Alwi, dkk.: 2002) Dengan kata lain kecerdasan emosional adalah kemampuan seseorang dalam mengendalikan dirinya. Daniel Goleman (2003) mengungkapkan bahwa manusia memiliki apa yang disebut dengan kendali batiniah. Menurutnya, disaat manusia harus membuat keputusan-keputusan, kata-hati menjadi indera manusia yang paling pure untuk mengerti tentang apa yang dirasa benar atau salah dan menyediakan informasi penting yang semestinya tidak diabaikannya yang dapat membuat penyesalan dikemudian hari. Kata hati sering dikenal dengan istilah hati nurani, kata hati tidak akan berbohong, jadi manusia yang memiliki kecerdasan emosional adalah dia yang mampu menuruti kata hatinya. Selanjutnya menurut Seto Mulyadi, kecerdasan emosional adalah kemampuan mengenali emosi diri, kemampuan memotivasi, kemampuan mengenali emosi orang lain, dan kemampuan membina hubungan dengan diri sendiri dan orang lain.

b. Ciri-ciri kecerdasan emosional

Menurut Goleman (2003) ciri-ciri orang yang memiliki kecerdasan emosional antara lain; 1) memiliki kemampuan untuk memotivasi diri; 2) mampu bertahan menghadapi frustrasi; 3) mampu mengendalikan dorongan hati; 4) mampu mengatur suasana hati; 5) mampu menjaga diri agar beban stres tidak melumpuhkan kemampuan berfikirnya; 6) mudah berempati; 7) suka berdo'a. Sementara itu jika laki-laki yang memiliki keceradasan emosional, ciri-cirinya adalah; 1) mantap secara emosional; 2) mudah bergaul dan jenaka; 3) tidak mudah takut; 4) tidak 
mudah gelisah; 5) mampu melibatkan diri dengan orang lain; 6) mampu melibatkan diri dari suatu permasalahan: 7) mampu memikul tanggung jawab; 8) mempunyai pandangan moral; 9) memiliki simpati dan empati; 10) menjalin hubungan dengan hangat dan antusias; 11) merasa nyaman dengan dirinya sendiri, dengan orang lain, dan dunia pergaulan dilingkunganya; dan 12) memiliki kehidupan emosional yang kaya tetapi wajar.

Demikian juga dengan perempuan yang memiliki kecerdasan emosional memiliki ciri-ciri sebagai berikut; 1) cenderung bersikap tegas; 2) mampu mengungkapkan perasaan secara langsung; 3) memandang dirinya secara positif; 4) kehidupanya memberi makna pada mereka; 5) mudah bergaul dan ramah; mengungkapkan perasaanya dengan wajar (bukan secara meledak-ledak kemudian menyesalinya); 7) mampu menyesuaikan diri dengan beban stress; 8) kemantapan pergaulannya membuat mereka mudah menerima orang baru; 9) cukup nyaman dengan dirinya sendiri sehingga selalu ceria, spontan, dan terbuka terhadap pengalaman sensual; 10) jarang merasa cemas atau bersalah dan mengalami kemurungan.

Orang yang memiliki kecerdasan emosional yang tinggi biasanya akan menjadi sosok yang lebih humanis. Unsurunsur utama kecerdasan emosional yang menjadikan individu lebih humanis menurut Goleman (2003) antara lain ; 1) kesadaran diri/mampu mengenali diri sendiri; 2) pengambilan keputusan pribadi; 3) mengelola perasaan; 4) menangani stres; 5) empati; 6) komunikasi; 7) membuka diri; 8) pemahaman/ mengindentifikasi pola kehidupan emosional dalam sisi yang positif, kekuatan dan kelebihan; 9) tanggung jawab pribadi; 10) ketegasan/tanpa marah; 11) dinamika kelompok; dan 12) menyelesaikan konflik. c. Kecerdasan emosional pada anak usia dini.

Keberadaan kecerdasan emosi seharusnya dimiliki oleh semua manusia dan semua tingkat usia, tidak terkecuali anak usia dini. Kalau diperhatikan muatan keerdasan emosional merupakan sesuatu hal yang tidak mudah dimiliki, karena hal tersebut berkaitan dengan suasana emosi orang perorang. Maka dalam target pencapaiannya, dikatakan sudah memiliki kecerdasan emosi atau belum memiliki bahkan tidak memiliki, sangat berkaitan dengan tingkat usia perkembangan anak. Adapun kecerdasan emosional pada anak usia dini menurut pendapat Wiyani (2014: 88) meliputi empat komponen yaitu; 1) kemampuan mengenali emosi diri; 2) kemampuan mengatur emosi diri; 3) kemampuan mengenali emosi orang lain; dan 4) kemampuan mengelola emosi orang lain. Sedangkan menurut Goleman (2003) terdapat tujuh unsur utama kecerdasan emosional anak usia dini, yaitu; 1) keyakinan; 2) rasa ingin tahu; 3) niat; 4) kendali diri; 5) keterkaitan; 6) kecakapan komunikatif; dan 7) kooperatif.

d. Urgensi kecerdasan emosi pada anak usia dini.

Kecerdasan emosi memiliki arti penting bagi anak usia dini, karena anak usia dini adalah makhluk yang baru belajar menapaki kehidupan dan tugas perkembangannya adalah belajar apapun. Dalam proses belajar diperlukan adanya modal yang cukup, agar tujuan belajar dapat tercapai. Proses belajar bukan sesuatu yang langsung jadi dan berhasil, diperlukan adanya usaha, perjuangan. Dengan dimilikinya kecerdasan emosi anak akan sangat terbantu dalam mencapainya. Menurut Wiyani (2014:92)) dengan kecerdasan emosi maka: 1) Dapat dijadikan sebagai alat pengendali diri agar terhindar dari tindakan-tindakan yang merugikan diri sendiri maupun orang lain dan makhluk 
disekitarnya; 2) Dapat dijadikan sebagai alat diteksi bagi orang tua dalam mengenali bakat dan minat anak usia dini; 3) Dapat dijadikan modal untuk mengembangkan potensi dirinya; 4) Dapat dijadikan modal memupuk jiwa kepemimpinannya dalam bidang apapun; 5) Dapat dijadikan alat, agar terhindar dari rasa cemas dan takut yang berlebih, kecenderungan menyendiri, rasa gugup dan minder; 6) Dapat dijadikan penggerak batin dalam berempati dengan orang lain.

\section{METODE}

Populasi penelitian ini ialah siswa TK Muslimat NU I Tuban yang jumlahnya 67 siswa, sedangkan sampel yang didapat sebanyak 40 siswa dengan penentuan sampel menggunakan teknik purposive sampling. Teknik pengumpulan data yang digunakan, meliputi metode angket, wawancara, observasi, dan dokumentasi. Metode observasi dilakukan untuk mendapatkan tambahan data perilaku siswa dan orang tua di sekolah. Metode dokumentasi dilakukan untuk memperoleh data siswa, guru dan sekolah. Sedangkan wawancara terhadap dewan guru dilakukan untuk mendapatkan tambahan informasi dan keabsahan data peneliti. Metode angket terdiri dari dua bagian, yaitu angket mengenai kecerdasan emosi dan gaya orang tua/pola asuh orang tua.

Pertanyaan dalam angket kecerdasan emosi disusun berdasarkan konsep yang dikemukakan oleh Wiyani (2014) yang terdiri dari empat aspek, dan Goleman (2003) yang terdiri dari tujuh aspek. Pertanyaan dalam angket tentang kecerdasan emosional anak usia dini awalnya terdiri dari 40 pertanyaan. Setelah diuji validasi hasilnya, ada 10 pertanyaan yang gugur yaitu memiliki nilai koefisien $r$ dalam uji validitas data $<0,300$. Jadi, item pertanyaan yang digunakan dalam penelitian ialah sebanyak 30 item, yang terdiri dari item favorabel. Uji releabilitas pada ke-30 item pertanyaan telah dinyatakan memenuhi. Sehingga angket pertanyaan tentang kecerdasan emosional anak telah valid dan reliabel untuk digunakan dalam penelitian ini.

Angket mengenai gaya orang tua/pola asuh orang tua, item pertanyaannya mengacu pada pendapat John Gottman dan Joan DeClaire (1999). Item pertanyaan tentang gaya orang tua/pola asuh orang tua, tidak perlu diuji validitas dan realibilitasnya karena telah diuji laboratorium psikologi dan sudah merupakan pertanyaan baku. Empat gaya orang tua/pola asuh orang tua yaitu: 1) mengabaikan; 2) tidak menyetujui: 3) laissez faire; dan 4) pelatih emosi. Angket tersebut diisi oleh orang tua siswa karena siswa TK belum bisa membaca.

Teknik analisa data yang digunakan ialah regresi linear berganda. Sebelum melakukan analisis regresi, data yang telah terkumpul dilakukan uji asumsi klasik. Uji asumsi klasik tersebut terdiri dari uji normalitas, autokorelasi, multikolonieritas, heteroskedastisitas.

\section{HASIL DAN PEMBAHASAN Hasil}

Uji Asumsi Klasik, menurut Ghozali (2013), uji asumsi klasik terdiri dari normalitas autokorelasi, multikolonieritas, dan heteroskedastisitas. Berikut penjelasan uji asumsi klasik dalam penelitian ini.

1) Uji Normalitas

Uji normalitas bertujuan untuk menguji distribusi populasi masing-masing variabel normal atau tidak. Hasil uji normalitas data ialah signifikansi (Asymp Sig) sebesar 0,175 (tipe mengabaikan), 0,169 (tipe tidak menyetujui), 0,053 (tipe laizestaire), 0,126 (tipe pelatih emosi) dan 0,143 (kecerdasan emosi anak). Karena signifikansi $>0,05$, artinya distribusi untuk masing-masing variabel ialah normal. 
2) Uji Autokorelasi

Autokorelasi merupakan korelasi antara anggota observasi yang disusun menurut waktu dan tempat. Model regresi yang baik seharusnya tidak terjadi autokorelasi. Metode pengujian menggunakan Uji Durbin-Watson (DW test). Jika 'd' ialah nilai Durbin Watson, maka tidak terdapat autokorelasi jika $\mathrm{du}<\mathrm{d}$ $<$ (4-du). Didasarkan pada tabel Durbin Watson $\alpha=5 \%, \mathrm{~N}=40$, dan $\mathrm{k}$ (variabel independen) $=4$, maka nilai $\mathrm{du}=1,7209$ dan $(4-d u)=22791)$. Hail uji autokorelasi ialah nilai Durbin Watson sebesar 2,193 $(1,7209<2,193<2,2791)$, maka dapat disimpulkan bahwa tidak terjadi masalah autokorelasi.

3) Multikolonieritas Uji

Uji multikolonieritas dilakukan dengan melihat nilai tolerance dan inflation factor (VIF) pada model regresi. Variabel yang menyebabkan multikolinearitas dapat dilihat dari nilai tolerance yang lebih kecil dari pada 0,1 atau nilai VIF yang lebih besar dari pada nilai 10 (Priyatno Duwi, 2009). Tabel 1 berikut merupakan hasil Uji Multikolonieritas.

Tabel 1. Hasil Uji Multikolonieritas

\begin{tabular}{llll}
\hline & & \multicolumn{2}{c}{$\begin{array}{c}\text { Collinearity } \\
\text { Statistics }\end{array}$} \\
\cline { 2 - 4 } & & $\begin{array}{c}\text { Toleranc } \\
\text { Model }\end{array}$ & VIF \\
\hline 1 & (Constant) & & \\
\cline { 2 - 4 } & Mengabaikan &, 226 & 4,418 \\
\cline { 2 - 4 } & Tidak Menyetujui &, 359 & 2,789 \\
\cline { 2 - 4 } & Laizestaire &, 480 & 2,082 \\
\cline { 2 - 4 } & Pelatih Emosi &, 337 & 2,966 \\
\hline
\end{tabular}

a. Dependent Variable: Kecerdasan Emosi Anak Usia Dini

Dari Tabel 1 tersebut dapat dilihat bahwa nilai Tolerance keempat variabel lebih dari 0,10 dan VIF kurang dari 10 .
Maka, dapat disimpulkan bahwa tidak terjadi multikolinearitas antar variabel bebas.

4) Uji Heteroskedastisitas

Heteroskedastisitas adalah varian residual yang tidak sama pada semua pengamatan di dalam model regresi. Regresi yang baik seharusnya tidak terjadi heteroskedastisitas. Uji Heteroskedastisitas pada penelitian ini menggunakan menggunakan uji melihat pola titik-titik pada grafik regresi. Jika ada pola tertentu, seperti titik-titik yang ada membentuk suatu pola tertentu yang teratur (bergelombang, melebar, kemudian menyempit), maka terjadi heteroskedastisitas. Jika tidak ada pola yang jelas, seperti titik-titik menyebar di atas dan di bawah angka 0 pada sumbu $Y$, maka tidak terjadi heteroskedastisitas. Gambar 1 berikut merupakan hasil uji heteroskedastisitas.

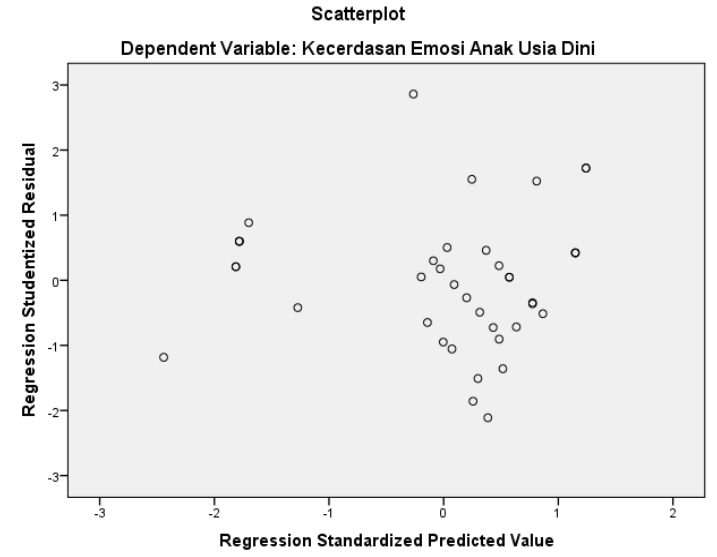

Gambar 1. Grafik Scatterplot

a. Analisis Regresi Berganda

Setelah uji asumsi klasik dilakukan, maka diperoleh simpulan bahwa model regresi telah memenuhi. Hasil analisis regresi linear berganda menunjukkan $\mathrm{F}$ hitung $>\mathrm{F}$ tabe $(33,144>2,641)$ dan signifikansi $<$ $0,05(0,000<0,05)$, maka $\mathrm{H}_{0}$ ditolak artinya, gaya orang tua mengabaikan, gaya orang tua tidak menyetujui, gaya orang tua laissez faire, dan gaya orang tua pelatih emosi secara bersama-sama mempengaruhi 
terhadap kecerdasan emosi anak usia dini di TK muslimat NU I Tuban.

\section{Tabel 2. Hasil analisis regresi berganda}

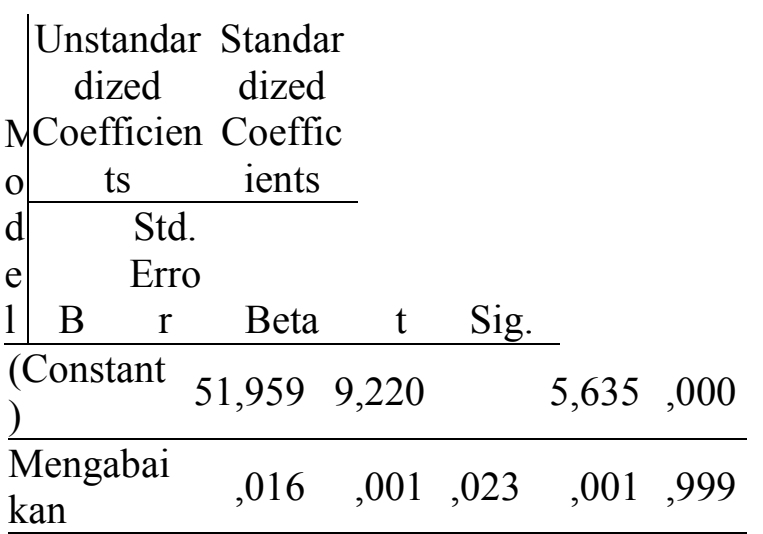

\begin{tabular}{llllll}
\hline $\begin{array}{l}\text { Tidak } \\
\text { Menyetuj }\end{array}$ &, 199 &, 079 &, 326 & 2,526 &, 016 \\
ui & & & & & \\
\hline $\begin{array}{l}\text { Laizestair } \\
\text { e }\end{array}$ &, 184 &, 075 &, 275 & 2,466 &, 019 \\
\hline $\begin{array}{l}\text { Pelatih } \\
\text { Emosi }\end{array}$ &, 293 &, 092 &, 426 & 3,202 &, 003
\end{tabular}

a. Dependent Variable: Kecerdasan Emosi Anak Usia Dini

1) $\quad 0,293$.

Kalau dilihat dari perolehan angka keempat gaya orang tua yang terbesar adalah gaya orang tua pelatih emosi, yaitu 0,293 artinya yang paling besar diantara gaya orang tua/pola asuh orang tua yang berpengaruh terhadap kecerdasan emosi anak usia dini adalah gaya orang tua pelatih emosi.

\section{Pembahasan}

Hasil penelitian menunjukkan bahwa, bagaimanapun bentuk gaya menjadi orang tua/pola asuh orang tua akan berpengruh terhadap kecerdasan emosi anak usia dini. Orang tua adalah penanggung jawab keluarga yang utama, sebagai pemegang kekuasaan penuh dan mutlak terhadap pengendali jalannya kehidupan sebuah rumah tangga atau keluarga. Dari orang tualah semua kebaikan dan keburukan diterima anak-anaknya, orang tua sebagai model dalam segala perilaku. Anak diasuh dalam tata cara yang membuat anak merasa nyaman, aman, penuh semangat, dan merasa diakui keberadaannya ataupun sebaliknya. Masih terdapat pemahaman yang kurang tepat bagi banyak orang tua, bahwa mereka hanyalah anak kecil yang belum tahu apa-apa, belum bisa merasakan apa-apa, belum punya kebutuhan apa-apa. Alhasil mereka adalah makhluk kecil yang ada diantara kita yang harus diatur dan dikendalikan terserah maunya orang dewasa. Dalam beberapa hal dapat dianggap seperti itu, tetapi dalam beberapa hal lain tidak dapat dianggap seperti itu, terutama dalam permasalahan kehidupan emosi anak.

Mencerdaskan emosi anak sudah menjadi tugas orang tua yang tidak dapat dianggap sepele dan ringan. Dalam tugasnya sebagai orang tua, dinamika dalam keluarga perlu dikendalikan melalui interaksi yang benar dan sehat. Interaksi yang dimaksudkan terutama dalam hal interaksi emosi antara orang tua dan anaknya. Interaksi emosional antara orang tua dengan anaknya dapat memiliki pengaruh yang lebih besar terhadap keejahteraan jangka panjang seorang anak. Pergaulan emosional anak dengan orang tua merupakan hal yang sangat penting, kasih sayang yang tepat antara anggota keluarga menjadi landasan bagi timbulnya nilai-nilai dan mengasuh manusia-manusia berakhlak.

Kehidupan yang semakin banyak tantangan ini, mau tidak mau harus dihadapi anak-anak pada saatnya nanti. Cerdas intelektual saja tidak cukup untuk menerobos tantangan-tantangan tersebut, keseimbangan yang diperlukan adalah dengan dimilikinya kecerdasan emosi. Dengan keerdasan emosi manusia mampu mengendalikan kemampuan dirinya, mampu merasakan apa yang dirasakan, 
mampu menyesuaikan dengan tuntutan lingkunagan dengan cara yang cerdas. Mampu mengenali keberadaan orang lain dengan lapang, bijaksana, mampu menghargai orang lain, tidak memaksakan, dan tidak merendahkan. Bahkan dikatakan untuk mencapai kesuksesan dalam menjalani kehidupan, dapat dimiliki oleh orang-orang yang memiliki kecerdasan emosi. Manusia yang cerdas emosinya dapat mengatur emosinya sendiri, memelihara semangatnya, mampu menenangkan diri sendiri, punya keyakinannya, penuh pengertian, tenang/stabil, cakap mengotrol diri, sukses dalam bekerja sama, dan sebagainya.

Dikutip dari pendapat Goleman (2003), banyak orang yang memiliki kecerdasan intelektual tinggi malah menjadi bawahan orang yang memiliki kecerdasan emosional tinggi. Bahkan pemimpin yang memiliki kecerdasan intelektual rendah ternyata memliki kecerdasan emosional yang tinggi. Kecerdasan emosional biasanya akan nampak dalam kemampuannya berempati pada orang lain, menunjukkan kegigihannya, ambisi pribadinya, dan memahami petunjuk-petunjuk. Lebih lanjut, Daniel Goleman (2003) mengatakan, dalam menentukan kesuksesan hidup, setinggi-tingginya kecerdasan intelektual hanya menyumbang 20\%. Sedangkan kecerdasan yang lainnya, termasuk kecerdasan emosional sebagai salah satu pengisi yang $80 \%$. Robert K. Cooper dan Ayman Sawaf (dalam Efendi, 2005) menegasakan bahwa sekarang ini hubungn antara kecerdasan intelektual dengan kesuksesan hidup hanya $4 \%$, artinya lebih dari 90\% kesuksesan hidup berhubungan dengan bentuk kecerdasan-kecerdasan lainnya, seperti kecerdasan emosi. Menurut Amstrong (2002), orang yang memiliki kecerdasan intelektual tinngi biasanya mengalami kesulitan dalam bergaul, kurang mengenali diri sendiri, memiliki masalah dengan kendali dorongan hati, atau tuna emosi (kesulitan menentukan apa yang dirasakan pada suatu saat). Dalam menjalani hidup lebih besar mengalami kesultan, walaupun prestasi sekolahnya cemerlang). Jadi dapat disimpulkan bahwa kecerdasan emosional sangat penting dimiliki oleh setiap manusia dalam menjalani kehidupan.

Sebagai orang tua, bagaimana upayanya agar dapat membentuk pribadipribadi yang cerdas emosi melalui gaya/pola pengasuhan yang tepat. Hal itu tentunya memerlukan niatan yang kuat, ikhlas tanpa pamrih, dan penuh rasa tanggung jawab. Seorang ahli psikologi dan penulis Emotional Intelligence Daniel Goleman (1995) mengatakan bahwa kehidupan keluarga merupakan sekolah kita yang pertama untuk mempelajari emosi. Di sekolah ini bukan saja bekerja melalui halhal yang dilakukan dan dikatakan oleh orang tua langsung kepada anak-anaknya, melainkan juga dalam contoh-contoh yang mereka berikan untuk menangani perasaan mereka sendiri dan hal-hal yang terjadi antara suami dan istri. Ada orang tua yang bisa menjadi guru emosi yang berbakat ada yang tidak (Goleman, 1995).

Apabila manusia tidak memiliki kecerdasan emosional, rata-rata mereka menjadi lebih resah dan gampang marah, lebih murung dan tidak bersemangat, lebih depresi dan kesepian, lebih mudah menurutkan kata hati/nafsu, cenderung selalu tidak patuh, dan lain sebagainya. Terjadinya banyak kejahatan dilingkungan sekitar kita, merupakan contoh tentang rendahnya kecerdasan emosi mayarakat kita. Kita harus merenungkan tentang kebobrokan emosi yang jelas/terangterangan dan lebih meluas "mengerikan". Contoh pada tingkatan yang paling rendah yaitu pada anak-anak, anak yang tidak dapat bekerja sama, kemampuan ini memang 
tidak mudah dilakukan anak, karena anakanak memiliki sifat egois yang tinggi. Sedangkan dalam bekerja sama, suatu saat harus mengalah, harus bergantian, kapan harus mempertahankan haknya, kapan harus membantu temannya, dan lain sebagainya. Contoh pada tingkatan remaja, anak yang mudah putus asa karena keinginannya tidak terpenuhi, malas/tidak bersemangat, melukai temannya bahkan membunuh. Contoh pada tingkatan orang dewasa, tega membunuh teman kerjanya karena tersinggung dengan perkataan yang merendahkan dirinya, merampok, termasuk, korupsi, dan sebagainya.

Kemampuan kecerdasan emosional tidak mudah untuk dimiliki, maka harus dilatihkan sejak dini, karena pada saat ini kecerdasan emosi sudah harus menjadi piranti penting bagi manusia dalam menempuh kehidupan yang sukses. Sama dengan begitu banyak orang tua "mampukah" untuk melatihkan. Ada keyakinan yang harus dimiliki oleh orang tua bahwa, "harus mampu", apabila orang tua mau melaksanakan pasti akan dapat tercapai. Berbeda dengan kecerdasan intelektual, merupakan sesuatu yang sudah dimiliki dari faktor bawaan atau faktor gen/keturunan dan tidak dapat dilatihkan. Kalau kita kembali kepada fungsinya, keluarga merupakan bentuk terkecil dari masyarakat yang ikut bertangung jawab dalam mencetak generasi bangsa. Maka melalui keluargalah kecerdasan emosi anak dapt dilatihkan dan dibentuk sejak dini melalui penerapan gaya menjadi orang tua atau pola asuh orang tua.

\section{KESIMPULAN}

Hasil penelitian ini menunjukkan bahwa $\mathrm{F}$ hitung $>\mathrm{F}$ tabe $(33,144>2,641)$ dan signifikansi $<0,05(0,000<0,05)$, maka $\mathrm{H}_{0}$ ditolak artinya, gaya orang tua mengabaikan, gaya orang tua tidak menyetujui, gaya orang tua laissez faire, dan gaya orang tua pelatih emosi secara bersama-sama mempengaruhi terhadap kecerdasan emosi anak usia dini di TK Muslimat NU I Tuban. Di antara keempat tipe pola asuh orang tua tersebut, tipe orang tua pelatih emosi ialah yang paling memiliki pengaruh terbesar pada kecerdasan emosional anak usia dini di TK Muslimat NU 1 Tuban. Dilihat dari persamaan regresi yang dihasilkan dari analisis statistic berikut, $\mathrm{Y}^{\prime}=$ $51,959+0,016 \mathrm{X} 1+0,199 \mathrm{X} 2+0,184 \mathrm{X} 3+0,29$ $3 \mathrm{X} 4$, X4 yang merupakan tipe pola asuh orang tua pelatih emosi menghasilkan 0,293, yang artinya setiap peningkatan Tipe Pola Asuh Orang Tua Pelatih Emosi sebesar 1, maka Kecerdasan Emosi anak Usia Dini juga meningkat sebesar 0,293.

Dari hasil penelitian tentang pola asuh orang tua terhadap kecerdasan emosi anak usia dini di TK Muslimat NU I Tuban yang telah dipaparkan diatas, maka orang tua siswa di TK tersebut:
1) Hendaknya memperhatikan kebutuhan anak-anaknya.
2) Selalu menjalin hubungan yang wajar dan nyaman dengan anak-anaknya.
3) Senantiasa menjadi contoh atau model bagi anak-anaknya.
4) Hendaknya menjaga suasana atmosfir dalam rumah tangganya.
5) Hendaknya mampu mengamati dan peka terhadap perubahan pada anak- anaknya

\section{UCAPAN TERIMA KASIH}

Ucapan terimakasih diucapkan kepada Kepala Sekolah NU 1 Tuban atas kesempatan yang diberikan untuk mengadakan penelitian.

\section{DAFTAR PUSTAKA}

Amstrong, Thomas. 2002. Setiap Anak Cerdas: Panduan Membantu Anak 
Belajar Dengan Memanfaatkan Multiple Intelligence-nya. Terj. Rina Buntaran. Jakarta: Gramedia Pustaka Utama.

Amstrong, Thomas. 2013. Kecerdasan Multiple di dalam Kelas. Terjemahan: Dyah Widya Prabaningrum. Jakarta: Indeks.

Efendi, Agus. 2005. Revolusi Kecerdasan Abad 21: Kritik MI, EI, SQ, AQ dan Successful Intelligence atas IQ. Bandung: Alfabeta.

Ghozali, Imam. 2013. Aplikasi Analisis Multivariate Dengan Program SPSS. Edisi Ketujuh. Semarang: Badan Penerbit Universitas Diponegoro.

Goleman, Daniel, 1995. Emotional Intelegence. New York: Bantam.

Goleman, Daniel. 2003. Kecerdasan Emosional: Mengapa EI lebih Penting daripada IQ. Terjemahan: T. Hermaya. Jakarta: Gramedia Pustaka Utama.

Gottman, John dan DeClaire, Joan. 1999. Kiat-kiat Membesarkan Anak yang Memilik Kecerdasan Emosional. Jakarta: Gramedia.

Hasan, Aliah B. Purwakania. 2006. Psikologi Perkembangan Islami: Menyingkap Rentang Kehidupan Manusia dari Prakelahiran hingga Pascakematian. Jakarta: Rajawali Perss.

Alwi, Hasan dkk. 2002. Kamus Besar Bahasa Indonesia. Jakarta: Balai Pustaka.

Hidayah, R., Eka Y., dan Yulian W.U. 2013. Hubungan Pola Asuh Orang Tua
Dengan Kecerdasan Emosional Anak Usia Prasekolah (4-6 tahun) di TK Senaputra Kota Malang. Jurnal Keperawatan ISSN 2086-3071.Diakses tanggal $17 \quad$ Februari 2018. http://ejournal.umm.ac.id.

Hurlock, 1974. Personality Development. New York: McGraw-Hill Publish-ing Co, Ltd.

Lazarus, Richard. 1976. Pattern of Adjustment. Tokyo: Mcgraw-Hill Kogakusha.

Priyatno, Duwi. 2009. 5 Jam Belajar Olah Data Dengan SPSS 17. Jogjakarta: CV. Andi Offset.

Pujiharti, I. dan Mathilda R.H. 2016. Hubungan Pola Asuh Orang Tua Dengan Kecerdasan Emosional Anak Prasekolah (3-6 tahun) di Raudatul Atfal (RA) Al-Muttaqin Jati Bening Baru Tahun 2016. Diakses tanggal 17 Februari 2018. http://uia.ac.id/

Susanto, Ahmad. 2015. Bimbingan \& Konseling di Taman Kanak-kanak. Jakarta: Prenadamedia.

Syamsu, Yusuf. 2005. Psikologi Perkembangan Anak dan Remaja. Bandung: PT Remaja Rosdakarya.

Syaodih, Ernawulan. 1999. "Peranan Bimbingan Guru, Pengasuhan Orang Tua, dan Interaksi Teman Sebaya terhadap Perkembangan Perilaku Sosial Anak". Tesis. Bandung. Tidak diterbitkan. 